\title{
Mango Peel Pectin: Recovery, Functionality and Sustainable Uses
}

\author{
Malaiporn Wongkaew ${ }^{1,2,+} \mathbb{D}$, Pikulthong Chaimongkol ${ }^{3,+}$, Noppol Leksawasdi 4,5 (D), \\ Kittisak Jantanasakulwong 4,5, Pornchai Rachtanapun 4,5 (D), Phisit Seesuriyachan 4,5, Yuthana Phimolsiripol 4,5 ${ }^{10}$, \\ Thanongsak Chaiyaso ${ }^{4,5}$, Warintorn Ruksiriwanich ${ }^{6,7} \mathbb{D}$, Pensak Jantrawut ${ }^{6,7}$ and Sarana Rose Sommano ${ }^{2,5,7, * \mathbb{D}}$
}

Citation: Wongkaew, M.; Chaimongkol, P.; Leksawasdi, N.; Jantanasakulwong, K.; Rachtanapun, P.; Seesuriyachan, P.; Phimolsiripol, Y.; Chaiyaso, T.; Ruksiriwanich, W.; Jantrawut, P.; et al. Mango Peel Pectin: Recovery, Functionality and Sustainable Uses. Polymers 2021, 13, 3898. https://doi.org/10.3390/ polym13223898

Academic Editors: Huihuang Ding and Qingbin Guo

Received: 12 October 2021

Accepted: 6 November 2021

Published: 11 November 2021

Publisher's Note: MDPI stays neutral with regard to jurisdictional claims in published maps and institutional affiliations.

Copyright: (c) 2021 by the authors Licensee MDPI, Basel, Switzerland. This article is an open access article distributed under the terms and conditions of the Creative Commons Attribution (CC BY) license (https:// creativecommons.org/licenses/by/ $4.0 /)$.
1 Program in Food Production and Innovation, College of Integrated Science and Technology, Rajamangala University of Technology Lanna, Chiang Mai 50220, Thailand; malaiporn@rmutl.ac.th

2 Plant Bioactive Compound Laboratory, Faculty of Agriculture, Chiang Mai University, Chiang Mai 50200, Thailand

3 Program in General Education, College of Integrated Science and Technology, Rajamangala University of Technology Lanna, Chiang Mai 50220, Thailand; c.pikulthong@rmutl.ac.th

4 School of Agro-Industry, Faculty of Agro-Industry, Chiang Mai University, Chiang Mai 50100, Thailand; noppol@hotmail.com (N.L.); jantanasakulwong.k@gmail.com (K.J.); pornchai.r@cmu.ac.th (P.R.); phisit.s@cmu.ac.th (P.S.); yuthana.p@cmu.ac.th (Y.P.); thanongsak.c@cmu.ac.th (T.C.)

5 Cluster of Agro Bio-Circular-Green Industry (Agro BCG), Chiang Mai University, Chiang Mai 50100, Thailand

6 Department of Pharmaceutical Sciences, Faculty of Pharmacy, Chiang Mai University, Chiang Mai 50200, Thailand; warintorn.ruksiri@cmu.ac.th (W.R.); pensak.j@cmu.ac.th (P.J.)

7 Cluster of Research and Development of Pharmaceutical and Natural Products Innovation for Human or Animal, Chiang Mai University, Chiang Mai 50200, Thailand

* Correspondence: sarana.s@cmu.ac.th; Tel.: +66-5394-4040

+ These authors contributed equally as the first author.

Abstract: Concerns regarding the overconsumption of natural resources has provoked the recovery of biopolymers from food processing biomass. Furthermore, the current market opportunity for pectin in other areas has increased, necessitating the search for alternative pectin resources. This is also a step towards the sustainable and circular green economy. Mango peel is the byproduct of agro-processing and has been used for high value-added components such as polysaccharide biopolymers. Pectin derived from the peel is yet to be exploited to its greatest extent, particularly in terms of its separation and physiochemical properties, which limit its applicability to dietary fiber in culinary applications. The functionality of the mango peel pectin (MPP) strongly depends on the molecular size and degree of esterification which highlight the importance of isolation and characterisation of pectin from this novel resource. This article therefore provides a useful overview of mango peel as a potential biomaterial for the recovery of MPP. Different extraction techniques and the integrated recovery were also discussed. The utilisation of MPP in different industrial schemes are also detailed out from different perspectives such as the pharmaceutical and biotechnology industries. This review convincingly expresses the significance of MPP, providing a sustainable opportunity for food and pharmaceutical development.

Keywords: extraction technique; fruit characteristic; mango peel biorefinery; pectic polysaccharide; pectin source

\section{Introduction}

Fruits are widely used in agri-food industry in which large quantity of by-products including pomace, peel, rind and seeds are generated [1,2]. This biomass is a potential source for valuable bioactive compound recovery such as dietary fibres, carotenoids, polyphenols, oils, vitamins and many other compounds [3]. Mango is one of the most consumed tropical fruits, known for its high nutritive values and extensively cultivated in the tropical and sub-tropical regions. Several preserved products of mango are commercially needed such 
as can, dried mango, frozen slices, purée, juices and nectar [4-6]. It is estimated that around 200,000 tons of biomass are generated during these processing and peels account for as high as $25 \%$ of the volume [7]. So far, attempts have been made in trying to value-add such the biomass from mango processing using integrated refinery approaches [8-13]. Besides its high contents of carbohydrates, proteins, fats and various classes antioxidants such as polyphenols, carotenoids and vitamins [14-17], this high-volume biomass is known as a potential source of dietary fibre [10,18-20]. The soluble dietary fibre is a carbohydrate polymer with more than 10 monomeric units that makes it is difficult to be hydrolysed by endogenous enzymes in the human small intestine [21,22]. They include pectin, galactomannan, inulin, gum while pectin is of high commercial need for functional foods and pharmaceutical applications [23-26]. Besides, mango peel contains high cellulose content $(30 \%)$ and lignin $(16 \%)[27,28]$. As a result, it was employed as a novel source for biopolymer recovery. Additionally, it comprises of $5-20 \%$ of pectin with variable contents of galacturonic acid, dependent upon the extraction methods and the cultivars [10,18-20]. To extract such the value-added biopolymers, the integrated isolation approach can be used [29].

The global need for pectin as biopolymer amounted to $\$ 1$ billion in 2019 and is expected to rise to $\$ 1.5$ billion in 2025 [26]. Commercial pectin is mainly recovered from either apple pomace or citrus peel which are of different physicochemical functionalities based up on the presence of pectin esterase of the raw materials [30]. Apple pomace pectin forms a gel of high viscosity which is suitable as a medicinal polymer, while the lighter colour of citrus pectin is preferable in the confectionery industry. Biopolymer pectin for industry requires a minimum of $65 \%$ of galacturonic acid on ash and moisture-free substances which limit other potential new resources for pectin recovery. In recent years, the recovery of non-starch polysaccharides from fruit by-products has become a promising strategy for the development of natural biopolymers [31]. Besides these, the information on mango peel pectin (MPP) as a potential biopolymer for industrial applications is not collective. In this study, the characteristics, value adding components and biorefinery process of mango peel are discussed. Featuring the most-sought after pectin biopolymer, its chemical structures and different extraction processes are highlighted along with possible applications in different industries are collectively presented. This review provides a useful baseline for substantial production of MPP as well as a guidance for the global policy of zero-waste processing and sustainable used of natural resource.

\section{Mango Peel as the Novel Source for Pectin Biopolymer}

\subsection{Mango Variety}

A wide range of mango varieties are cultivated including those of native and new bred cultivars. Therefore, the yield and the physiological attributes are diverse, depending on their gene pools and further interaction with environmental conditions [32,33]. Physical characteristics such as fruit weight, size and peel colour have been used to describe mango varieties. These physical attributes also play a crucial role in consumption and industrial processing. The commercial attributes of mango physiology are illustrated in Table 1 . The CIE colour space $\left(\mathrm{L}^{*}, \mathrm{a}^{*}, \mathrm{~b}^{*}\right)$ has been used to determine maturity index and the ripening process of mangoes $[34,35]$. The information of length, width and breadth of mango fruits are used for arithmetic mean diameter $\left(D_{a}\right)$ and geometric mean diameter [36] data calculation. These values are regarded as physical parameters during fruit grading [37]. Likewise, the ratio of width-to-length or aspect ratio $\left(R_{a}\right)$ indicates an ellipsoid shape during the process of fruit development [38]. The greater value of $R_{a}$ signifies more advanced ripening stages of the fruits [39]. In addition, specific gravity as defined as fruit soluble matters of the sugar contents along with firmness alteration can be typical used to define the stage of maturity [5]. It is worth highlighting that both parameters intercorrelate with each other, and greater values of $R_{a}$ and sphericity denote an advanced stages of fruit ripening [39]. Moreover, a higher fruit ripeness leads to a greater content of pectin from fruit peel [40]. Wongkaew et al. [6] reported that the physical properties of fruit physical 
properties (Colour, $D_{a}, D_{g}, R_{a}$, sphericity, surface area and percentage yield of fruit parts) can be used to distinguish mango varieties.

The morphology of mango fruit comprises of three parts, namely pulp (mesocarp), peel (epicarp) and seed kernel (endocarp), as illustrated in Figure 1. Mango pulp is a source of a variety of phytochemical components including those of reducing sugars, amino acids, aromatic compounds as well as functionally active ingredients, such as pectin, vitamins, anthocyanins and polyphenols [41]. In processing, pulp is the most-consumed parts of the fruit, while the peel and seed are usually discarded (accounted for $35-60 \%$ of the total fruit weight) as biomass [7]. Peel ( $5-17 \%)$ and seed ( 7-17\%) are known as byproducts of mango processing and the amount depends on mango varieties. These are, indeed, the potential resource for natural product biorefinery.

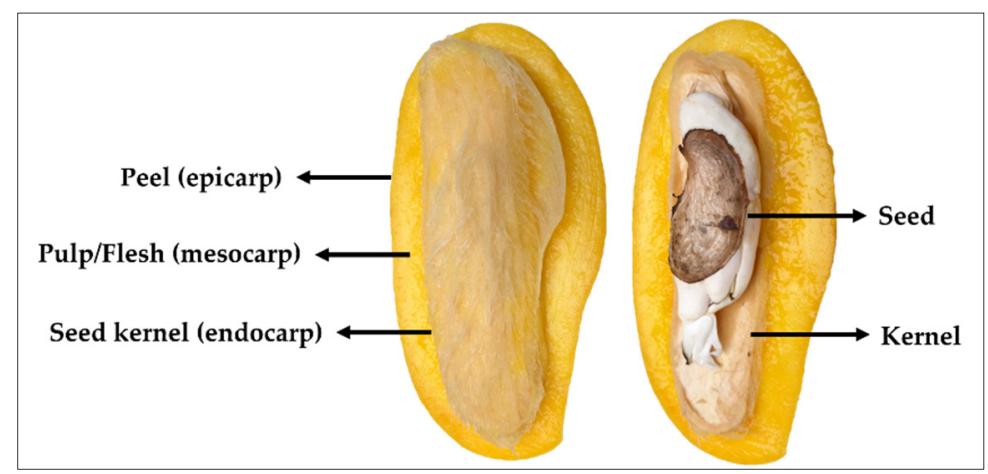

Figure 1. The biomass composition of mango fruit.

Table 1. Physical characteristics of different ripe mango varieties.

\begin{tabular}{|c|c|c|c|c|c|c|c|c|c|c|c|}
\hline \multirow{2}{*}{$\begin{array}{c}\text { Mango } \\
\text { Varieties }\end{array}$} & \multicolumn{3}{|c|}{ Colour } & \multirow{2}{*}{$\begin{array}{c}\text { Length } \\
(\mathrm{mm})\end{array}$} & \multirow{2}{*}{$\begin{array}{l}\text { Width } \\
(\mathrm{mm})\end{array}$} & \multirow{2}{*}{$\begin{array}{c}\text { Breadth } \\
(\mathrm{mm})\end{array}$} & \multirow{2}{*}{$\begin{array}{l}\text { Volume } \\
(\mathrm{mL})\end{array}$} & \multirow{2}{*}{$\begin{array}{c}\text { Flesh } \\
\text { Weight } \\
(\%)\end{array}$} & \multirow{2}{*}{$\begin{array}{c}\text { Peel } \\
\text { Weight } \\
(\%)\end{array}$} & \multirow{2}{*}{$\begin{array}{c}\text { Seed } \\
\text { Weight } \\
(\%)\end{array}$} & \multirow{2}{*}{ References } \\
\hline & $\mathbf{L}^{*}$ & $a^{*}$ & $\mathbf{b}^{*}$ & & & & & & & & \\
\hline Mahachanok & 68.83 & 3.28 & 40.66 & $165.05^{* *}$ & $66.42^{* *}$ & $58.30 * *$ & $313.89 * *$ & 66.69 & 16.64 & 16.66 & \multirow{4}{*}{ [6] } \\
\hline Chok Anan & 69.98 & 5.55 & 43.09 & $111.77^{* *}$ & $74.80^{* *}$ & $63.1^{* *}$ & $217.49^{* *}$ & 67.32 & 14.32 & 18.29 & \\
\hline Nam Dok Mai & 72.26 & 6.74 & 36.63 & $140.14^{* *}$ & $70.61 * *$ & $62.10^{* *}$ & $271.47^{* *}$ & 73.15 & 14.42 & 12.43 & \\
\hline Kaew & 67.68 & 3.41 & 39.70 & $112.16^{* *}$ & $70.66^{* *}$ & $62.45 * *$ & $209.54 * *$ & 70.32 & 15.60 & 14.08 & \\
\hline Rad & 47.19 & 0.26 & 17.03 & 98.47 & 51.67 & 45.89 & $\mathrm{n} / \mathrm{a}$ & $\mathrm{n} / \mathrm{a}$ & 5.40 & $\mathrm{n} / \mathrm{a}$ & \multirow{3}{*}{ [13] } \\
\hline Ta Labnak & 33.09 & -6.01 & 9.51 & 87.26 & 81.47 & 69.17 & $\mathrm{n} / \mathrm{a}$ & $\mathrm{n} / \mathrm{a}$ & 6.00 & $\mathrm{n} / \mathrm{a}$ & \\
\hline Sampee & 47.43 & 3.28 & 20.36 & 93.62 & 55.69 & 47.65 & $\mathrm{n} / \mathrm{a}$ & $\mathrm{n} / \mathrm{a}$ & 7.60 & $\mathrm{n} / \mathrm{a}$ & \\
\hline Nyala & $\mathrm{n} / \mathrm{a}$ & $\mathrm{n} / \mathrm{a}$ & $\mathrm{n} / \mathrm{a}$ & 83.00 & 83.00 & $\mathrm{n} / \mathrm{a}$ & 150.00 & 82.10 & 10.70 & 7.20 & \multirow{3}{*}{ [42] } \\
\hline Edelfursan & $\mathrm{n} / \mathrm{a}$ & $\mathrm{n} / \mathrm{a}$ & $\mathrm{n} / \mathrm{a}$ & 92.00 & 92.00 & $\mathrm{n} / \mathrm{a}$ & 250.00 & 81.57 & 10.53 & 7.90 & \\
\hline Kaboom & $\mathrm{n} / \mathrm{a}$ & $\mathrm{n} / \mathrm{a}$ & $\mathrm{n} / \mathrm{a}$ & 95.00 & 95.00 & $\mathrm{n} / \mathrm{a}$ & 300.00 & 82.40 & 10.60 & 7.00 & \\
\hline Alphonso & $\mathrm{n} / \mathrm{a}$ & $\mathrm{n} / \mathrm{a}$ & $\mathrm{n} / \mathrm{a}$ & 94.60 & 73.40 & 60.60 & 214.40 & 74.58 & 14.19 & 11.22 & \multirow{3}{*}{ [43] } \\
\hline Kesar & $\mathrm{n} / \mathrm{a}$ & $\mathrm{n} / \mathrm{a}$ & $\mathrm{n} / \mathrm{a}$ & 95.70 & 65.70 & 58.00 & 188.80 & 71.28 & 13.06 & 15.66 & \\
\hline Totapuri & $\mathrm{n} / \mathrm{a}$ & $\mathrm{n} / \mathrm{a}$ & $\mathrm{n} / \mathrm{a}$ & 123.60 & 70.80 & 66.60 & 261.50 & 71.33 & 16.42 & 12.25 & \\
\hline
\end{tabular}

${ }^{* *}$ unpublished data by the first author; $\mathrm{n} / \mathrm{a}=$ not available.

\subsection{Value-Added Components from Mango Peel}

As mentioned, peel and seed are the major by-products of the mango processing industry. These biomasses are usually buried in landfill or used as animal feed that; the fermentation process is generally toxic to the soil [44]. Previous reports claimed that mango peel consists of various valuable phytochemicals, including pectin, carotenoids, polyphenols and other bioactive compounds that can be used in the pharmaceutical industry $[8,17,22,45]$. However, these compositions are variable depending on the maturity stage, locality, variety and climatic conditions where mangoes are produced.

As presented in Table 2, mango peel contains a variety of macronutrients viz., carbohydrates, protein, lipid and crude fibre. Crude fibre is an important element to determine 
the significance of the by-products as sources of pectin recovery. In mango peel, the fibre content ranges between $2-20 \%$ of the total mass. While citrus peels contain as high as $(>50 \%)$ dietary fibre and different varieties are currently used as raw material for citrus peel pectin including those from Valencia orange [46], Persia lime [46], lemon [47] and sweet orange [47]. Owing to its high fibre content, the peel can be used as an additive ingredient to enhance the functional properties of food and feed [48,49]. Calcium is the largest mineral constituent in the peel followed by magnesium, potassium and sodium, respectively [7]. The content of vitamin $C$ ranges from $18-257 \mathrm{mg} \cdot \mathrm{g}^{-1}$, depending again on the varieties. The vitamin $\mathrm{E}$ of ripened mango peel is of a greater concentration than the green peel [41].

The polyphenol content in the peel varies from $55-110 \mathrm{mg} \cdot \mathrm{g}^{-1} \mathrm{dry}$ weight and higher levels are found in the ripe fruit than they are in the unripe peel [16]. The peel is also the major source of polyphenols that are basically higher than the pulp at all growth stages [50,51]. Mangiferin (C-glucosyl xanthone), a heat-stable and pharmacologically active phytochemical, is typically found in high content of mango peel. Mangiferin illustrates various bioactivities such as antiinflammation, anti-diabetic, immunomodulatory, antitumor and antioxidant [52]. The amount of mangiferin and its derivatives is greater in the peel than in the pulp [53]. As a result of its functional properties, mangiferin is commercially used in term of therapeutic and cosmetics products [54] and food supplements [55].

Anthocyanins, water-soluble pigments, add red, blue and purple colours to the peels of mangoes. The compounds are known for their beneficial effects in the prevention of various diseases such as cancer, diabetes and neuronal and cardiovascular diseases, thereby promoting human health $[56,57]$. Total anthocyanin content ranges from $3600-5650 \mu \mathrm{g} \cdot \mathrm{g}^{-1}$ in the fully ripe stage and from $2030-3260 \mu \mathrm{g} \cdot \mathrm{g}^{-1}$ in the raw and unripe stages [16]. The major anthocyanins detected in various varieties of mangoes, namely cyanidin, pelargonidin, delphinidin, malvidin, petunidin and peonidin [58]. Regarding to their biological properties, anthocyanins are comprehensively used as a substitute for artificial colorants in foods and beverages $[59,60]$.

Carotenoids are fat-soluble pigments that give peels and flesh their yellow, orange and red colours. Mango peel contains high concentrations of carotenoids in the form of $\beta$-carotene, a precursor for vitamin A [61]. The content of carotenoids generally increases during ripening and is the highest at the fully-ripe stage [58]. Consumption of carotenoids reduces the risk of developing certain cancers (cervical, ovarian, colorectal, prostate, breast), cardiovascular disease, bone, skin, or eye disorders, mental health, metabolic health, during pregnancy and early life and even provide cosmetic benefits [62,63]. As a result, carotenoids are also widely used in food as a colourant, antioxidant and additive [64].

Table 2. Nutritional and phytochemical compositions of mango peel $[6,13,41,49,65-69]$.

\begin{tabular}{cc}
\hline Compounds & Content \\
\hline Water & \\
Carbohydrate & $31.30-76.70$ \\
Protein & $10.53-30.80$ \\
Total lipid & $2.10-8.06$ \\
Total sugar & $1.40-2.48$ \\
Total dietary fibre & 25.00 \\
Minerals $\left(\mathrm{mg} \cdot 100 \mathrm{~g}^{-1}\right)$ & $1.40-20.53$ \\
Calcium & 150 \\
Iron & 40.6 \\
Magnesium & 100 \\
Potassium & 75 \\
Sodium & 50 \\
Copper & 10.4 \\
\hline
\end{tabular}


Table 2. Cont.

\begin{tabular}{|c|c|}
\hline Compounds & Content \\
\hline \multicolumn{2}{|l|}{ Vitamins } \\
\hline Vitamin C (total ascorbic acid, $\mathrm{mg} \cdot 100 \mathrm{~g}^{-1}$ ) & $18-257$ \\
\hline Vitamin A (retinol activity equivalent, $\mu \mathrm{g} \cdot 100 \mathrm{~g}^{-1}$ ) & 100 \\
\hline Vitamin E ( $\alpha$-tocopherol, $\left.\mathrm{mg} \cdot 100 \mathrm{~g}^{-1}\right)$ & $0.25-0.59$ \\
\hline \multicolumn{2}{|l|}{ Polyphenols $\left(\mathrm{mg} \cdot 100 \mathrm{~g}^{-1}\right.$ ) } \\
\hline Kaempferol & 3.6 \\
\hline Mangiferin & 169 \\
\hline Mangiferin gallate & 321 \\
\hline Isomangiferin & 13.4 \\
\hline Quercetin & 6.5 \\
\hline Rhamnetin 3-0 galactoside/glucoside & 9.4 \\
\hline \multicolumn{2}{|c|}{ Flavonoids (catechin equivalent $100 \mathrm{~g}^{-1}$ ) } \\
\hline Anthocyanins $(\mu \mathrm{g})$ & $3600-5650$ \\
\hline Cyanidin & 22.10 \\
\hline Pelargonidins & 22.73 \\
\hline Delphinidins & 18.02 \\
\hline Malvidins & 5.26 \\
\hline Petunidins & 21.60 \\
\hline Peonidins & 24.42 \\
\hline Carotenoids ( $\mu \mathrm{g})$ & 3092 \\
\hline$\beta$-carotene & 1310 \\
\hline$\beta$-cryptoxanthin & 600 \\
\hline Lutein and zeaxanthin & 299 \\
\hline
\end{tabular}

\subsection{High Value-Added Components Biorefinery}

Table 3 details out research studies on the phytochemical biorefinery of mango byproduct, mainly peel. The biorefinery not only value-adds the biomass but also reduces the biomass volume from the industrial processing of mango. Owing to a disposal of the loss, transportation costs and limited availability of landfills are questionable for sustainable processing. Thereby, mango peel valorisation through different techniques would undoubtedly eliminate the disposal problem.

Table 3. Current research studies on mango peel biorefinery of various value-add products.

\begin{tabular}{|c|c|c|}
\hline Biorefinery Aspects & Products & References \\
\hline \multirow{6}{*}{ Biotechnological aspects } & Ethanol production & {$[27,70]$} \\
\hline & Wine fermentation & [71] \\
\hline & $\begin{array}{c}\text { Enzyme production } \\
\text { - Carboxymethyl cellulase } \\
\bullet \text { Cellulase } \\
\bullet \text { Pectinase }\end{array}$ & [72-74] \\
\hline & Lactic acid production & [75] \\
\hline & Single cell protein production & [76] \\
\hline & Sugar source & [77] \\
\hline \multirow{5}{*}{$\begin{array}{l}\text { Sources for functional } \\
\text { ingredients }\end{array}$} & Pectin & {$[6,10,12,13]$} \\
\hline & Phenolic compounds & [78-80] \\
\hline & Carotenoid & {$[16,71]$} \\
\hline & $\begin{array}{l}\text { Functional food ingredient } \\
\text { - Noodles, bread, biscuits, sponge } \\
\text { cakes, other bakery products } \\
\text { and yogurt }\end{array}$ & {$[81,82]$} \\
\hline & $\begin{array}{l}\text { Dietary fibre } \\
\text { - Macaroni } \\
\text { - Beef burger }\end{array}$ & $\begin{array}{l}{[83]} \\
{[78]}\end{array}$ \\
\hline \multirow{2}{*}{ Other application areas } & Removal of heavy metals & [84] \\
\hline & Pharmaceutical excipient & {$[20,85]$} \\
\hline
\end{tabular}




\section{Mango Peel Pectin}

\subsection{Mango Peel Pectin Recovery}

General pectin recovery includes a raw material pre-treatment stage, an extraction operation and a post-extraction stage $[86,87]$. Nevertheless, the issue on the conventional process, particularly the extraction step, is whether or not it is worth the energy and economic demands that are currently required in the practice [88]. Therefore, several sustainable and quicker alternative approaches to extract pectin from biological materials have been developed. The innovative techniques for pectin extraction include enzymeassisted extraction, ultrasounds, subcritical fluids and microwave heating. The benefits and drawbacks of the techniques are compared as shown in Table 4.

\subsubsection{Conventional Heating Extraction (CHE)}

Pectin is traditionally extracted in water acidified with $0.05-2 \mathrm{M}$ sulfuric, nitric, phosphoric, acetic or hydrochloric acid between $80-100{ }^{\circ} \mathrm{C}$ for $1 \mathrm{~h}$ with continuous stirring [89]. Conventional extraction (solid-liquid extraction) depends on a number of factors such as temperature, $\mathrm{pH}$, solvent properties, solid to solvent ratio, dry solids, particle size and diffusion rate [90]. For pectin extraction, mango peel powder was initially treated with the acidified solution. Subsequently, the obtained solvent was treated with ethanol solution [91]. Through this method, an MPP yield as high as 30\% can be achieved from the residue with the degree of esterification (DE) varying from approximately 60 to $90 \%$ [10,91].

\subsubsection{Novel Extraction Techniques}

\section{- Microwave-Assisted Extraction (MAE)}

MAE involves dielectric heating of plant molecules through the exposure of microwaves. The microwave irradiation accelerates cell rupture by a sudden temperature rise and internal pressure increase inside the cells of plant sample, which promotes the destruction of sample surface and in turns the exudation of pectin within the plant cells into the surrounding solvents and increase [92-94]. The conventional "on-off" microwave operation, however, may lead to the overheating of the raw material, which may ultimately result in a low quality of MPP. Consequently, a phase controller (PCMAE), which regulates the electrical power input into the magnetron thereby generating smooth and adjustable microwave power was installed additionally for a better extraction performance [10]. The applications of the MAE for pectin extraction from mango peel were reported and the obtained pectin had higher content when compared with the CHE $[10,12]$. The microwave provides more efficient heat than the $\mathrm{CHE}$ approach due to the intense formation of vapour in polar substances generated by the electromagnetic field [95].

\section{- Enzyme-Assisted Extraction (EAE)}

The enzymes are used to improve extraction process by hydrolyzing matrix of the plant cell wall. Cell wall degrading enzymes with minimum pectinolytic activity are used to hydrolyze non-pectin plant cell wall components in enzymatic extraction of pectin [96,97]. The EAE depends on reaction time, type and concentration of enzyme, temperature, $\mathrm{pH}$ value and particle size of plant material $[98,99]$. The EAE technique was applied to recover pectin from multiple bioresources such as lime [100], passion fruit [101] and apple pomace [102]. The yields of pectin were achieved with the enzymatic extraction which were greater than that obtained with the CHE method. However, the pectin extraction from mango peel using this technology has not yet been implemented.

\section{- $\quad$ Ultrasound-Assisted Extraction (UAE)}

Sound waves consist of mechanical vibrations, which can be applied in treatments to the solid, liquid or gas with frequencies higher than $20 \mathrm{kHz}[99,103]$. Adapted for pectin extraction, the collapse of cavitation bubbles near cell walls induced by ultrasound produces cell disruption, thus causing stronger and enhanced solvent entrance into the cells and intensification of the mass transfer $[104,105]$. For pectin recovery, Guandalini 
et al. [106] found that the UAE provided an alternative choice for pectin extraction from mango peel because through this technique an MPP yield as high as $50 \%$ can be achieved without interfering the physicochemical properties (galacturonic acid content and degree of esterification).

\section{- $\quad$ Subcritical-Assisted Extraction (SWE)}

Subcritical water is liquid water at elevated pressure which is able to attain temperatures higher than its normal boiling point without a change in phase. When such water is used as solvent in extraction, the process is known as subcritical water extraction (SWE) also known as pressurized hot water extraction (PHWE) and superheated water extraction (SHWE) [107]. The SWE is stated as a green route for the valorisation of mango peel in form of pectin product. Xiaa and Matharu [108] reported that the MPP extracted by the SWE with no mineral acid supplementation resulted in a great yield of $18.34 \%$, while the $\mathrm{DE}$ of the pectin was more than $70 \%$.

Table 4. Benefits and drawbacks of the novel techniques.

\begin{tabular}{|c|c|c|}
\hline Extraction Techniques & Benefits & Drawbacks \\
\hline MAE & $\begin{array}{ll}- & \text { Reduce extraction time } \\
- & \text { Low solvent requirement } \\
- & \text { Improve the quality and quantity of pectin than } \\
\text { - } & \text { Conventional technique } \\
\text { [109,110] }\end{array}$ & $\begin{array}{l}\text { Corrosion problem on equipment } \\
\text { from acidified water used } \\
\text { [111] }\end{array}$ \\
\hline EAE & $\begin{array}{ll}- & \text { No use of acidic } \mathrm{pH} \text { levels and high temperature } \\
- & \text { No corrosion problem on equipment } \\
- & \text { Consider as green technology } \\
- & \text { Reduce need for certain pre-treatment steps } \\
- & \begin{array}{l}\text { Decrease in overall extraction time and a faster } \\
\text { extraction process }\end{array} \\
\text { - } & \begin{array}{l}\text { Improve the pectin quality due to the mild } \\
\text { condition of extraction }\end{array} \\
\text { [112-114] }\end{array}$ & $\begin{array}{l}\text { - } \quad \text { High cost of enzyme } \\
\text { - } \quad \begin{array}{l}\text { Scale-up of EAE process can be } \\
\text { difficult because of the uniqueness } \\
\text { in response of different enzymes to } \\
\text { changing environmental conditions }\end{array} \\
\text { [97] }\end{array}$ \\
\hline UAE & $\begin{array}{l}\text { - } \quad \begin{array}{l}\text { Reduce extraction time, reduced energy } \\
\text { consumption and a relatively lower use of solvent } \\
\text { - } \quad \text { Enhance the yield and kinetics of pectin during } \\
\text { recovery is biomass-specific plant }\end{array} \\
\text { [111,115] }\end{array}$ & $\begin{array}{l}\text { - } \begin{array}{l}\text { Does not greatly reduce solvent } \\
\text { requirement after all }\end{array} \\
\text { [116] }\end{array}$ \\
\hline SWE & $\begin{array}{ll}- & \text { High quality extracts } \\
- & \text { Quick extraction process } \\
- & \text { Save in solvent use (water) and } \\
- & \text { making this technique suitable for food and } \\
\text { pharmaceutical compounds }\end{array}$ & $\begin{array}{l}\text { - High cost of technique } \\
\text { implementation } \\
\text { - } \quad \text { Pectin degradation } \\
\text { [118] }\end{array}$ \\
\hline
\end{tabular}

\subsection{MPP Functionality}

Pectin is mostly extracted from various plant sources and is of great variation in term of quality. Consequently, pectin is purified and restructured in order to achieve constant and reproducible gel strength, for example HMP is improved its quality by dilution with sucrose. MPP is typical of high methoxyl content which is unable to form gel by interaction with calcium ions due to an insufficient number of carboxylic groups $[8,119]$. Thus, to improve its functionality for a specific purpose, de-esterification using either acidic or basic chemicals is necessary. The characteristic compositions of the extracted MPP are illustrated in Table 5. 
Table 5. Typical characteristics of mango peel pectin compared with commercial pectin.

\begin{tabular}{|c|c|c|c|c|}
\hline \multirow[b]{2}{*}{ Characteristics } & \multirow[b]{2}{*}{$\begin{array}{c}\text { Commercial Pectin } \\
{[120]}\end{array}$} & \multicolumn{3}{|c|}{ Mango Peel Pectin } \\
\hline & & CHE [106] & $\begin{array}{l}\text { UAE } \\
{[121]}\end{array}$ & $\begin{array}{c}\text { MAE } \\
{[6]}\end{array}$ \\
\hline Galacturonic acid (\%) & >65 (typically 75-80) & 76 & $52-53$ & $\mathrm{n} / \mathrm{a}$ \\
\hline Degree of esterification (\%) & $30-75$ & 61 & $56-93$ & $57-93$ \\
\hline Degree of acethylation & $\begin{array}{l}<5 \text { (except for e.g., sugar beet } \\
\text { pectin) }\end{array}$ & $\mathrm{n} / \mathrm{a}$ & $\mathrm{n} / \mathrm{a}$ & $\mathrm{n} / \mathrm{a}$ \\
\hline Neutral sugars (\%) & $<15 \%$ & $\mathrm{n} / \mathrm{a}$ & $\mathrm{n} / \mathrm{a}$ & $\mathrm{n} / \mathrm{a}$ \\
\hline Protein $(\mathrm{N} \times 6.25)(\%)$ & $<5 \%$ & $\mathrm{n} / \mathrm{a}$ & $4.7-5.9$ & $\mathrm{n} / \mathrm{a}$ \\
\hline Molecular weight $\left(\mathrm{g} \mathrm{mol}^{-1}\right)$ & $100,000-200,000$ & $\mathrm{n} / \mathrm{a}$ & $\begin{array}{l}378,400- \\
2,858,000\end{array}$ & $\mathrm{n} / \mathrm{a}$ \\
\hline
\end{tabular}

$\mathrm{n} / \mathrm{a}=$ not available; $\mathrm{CHE}=$ conventional heating extraction; UAE = ultrasound-assisted extraction; MAE = microwave-assisted extraction.

The residues of galacturonic acid (GA) (Figure 2a) are generally recognised as the backbone of the pectin structure. Its chemical structure composes of an aldehyde group at $\mathrm{C} 1$ and a carboxylic acid group at C6 [25]. The GA can be partially methyl-esterified at C6 with methanol and acetylated at the $\mathrm{O} 2$ or $\mathrm{O} 3$ positions with acetic acid (Figure 2b,c) [122]. The GA content can be determined by either the colorimetry [106] or high performance liquid chromatography [123]. The ratio of methyl-esterified galacturonic acid groups to the total galacturonic acid groups is defined as the degree of esterification (DE) [124-126]. The degree of esterification and acetylation of pectin affects the gelling properties of the pectin; a higher DE increases the capacity to form gels, whereas a higher degree of acetylation inhibits gelling [127]. The analytical quantification of DE include the titrimetric technique [106,128], gas liquid chromatography and colorimetric uronic acid analyses [129]. Furthermore, the content of GA in foods is very important because their presence can affect the chemical and sensorial characteristics of the matrix such as $\mathrm{pH}$, total acidity, microbial stability, sweetness, consumer acceptability and therefore, provide precious information on the wholesome quality of the food or on the optimisation needed to impart select technical features [130]. Meanwhile, the molecular weight of pectin depends on the raw materials and the extraction techniques. Bagherian et al. [109] reported that continued heating of pectin extraction may lead to pectin networks disaggregation, thus decreasing the molecular weight.

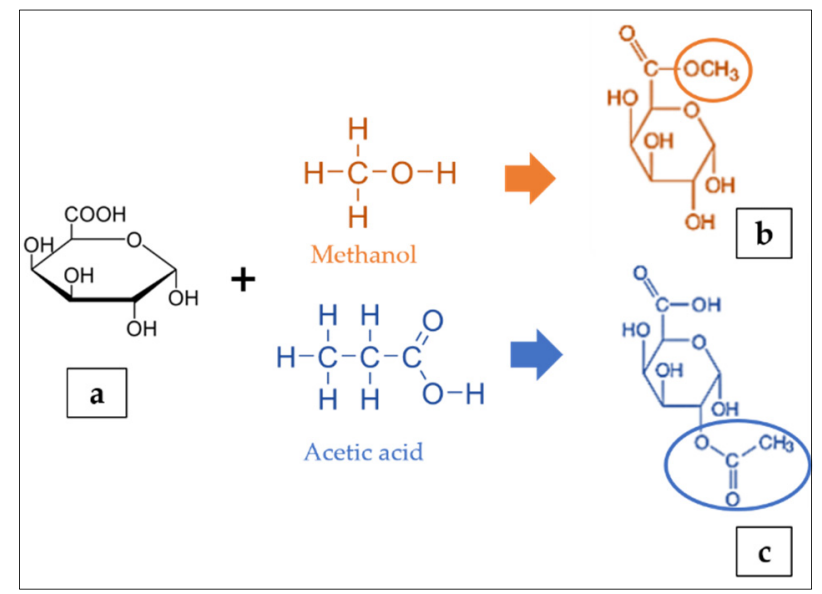

Figure 2. Structure of galacturonic acid (a) presenting methyl esterified (b) and acetylated (c) forms adapted from [122].

In case of pectin recovered from mango peel, the GalA contents varied depending on the extraction techniques. Process optimization of extraction methods to obtain the minimal GalA level of 65\% in MPP has been highlighted in many research studies [121,131,132]. Geerkens et al. [133] claimed that the preparation processes of the peel (blanching, particle size reduction) and fruit ripening stage reduced the GalA content, however the highest 
content obtained was $48 \%$. Regarding the DE content, the values were in a range between $56 \%$ and $93 \%$, which categorized it as high methoxyl pectin [134]. Both GalA and DE of pectic polysaccharides are involved in the commercial uses of pectin as gelling and thickening agents $[135,136]$.

\subsection{MPP Applications}

Pectins are widely used as additive in foods and beverages such as a gelling agent, thickener, texturiser, emulsifier and stabiliser [137]. In recent years, pectin has been applied as a fat or sugar alternative in low-calorie foods [12], dietetic food [138], food packaging [139] and drug carrier [119]. Selection of pectin for a particular food depends on many factors, including the texture required, $\mathrm{pH}$, processing temperature, presence of ions, proteins and the expected shelf life of the product [140]. MPP was recovered from peel of 'Nam dok mai' variety (Mox $>8 \%$ ) and was found suitable as fat replacement in a Chinese sausage formular in its original form and colour [12]. Additionally, MPP obtained from 'Chok anan' variety was utilised as a substrate for pectic oligosaccharide hydrolysate with pectinase. The digested monosaccharide compositions were mainly fructose and glucose while arabinose had prominent influence on prebiotic potentials of Bifidobacterium animalis [141]. Thin films have been used as food packaging polymer and many drug delivery systems of oral, buccal, and transdermal routes. In one study, thin film was fabricated from a mixture of LMP and MPP at 1:2 ratio with $40 \%(w / w)$ glycerol. The film attained the highest elongation at break $(8.80 \%)$ and lowest Young's modulus (83.19 MPa) with an increasing hydrophobicity when the content of MPP increased [8]. For a topical drug delivery, de-esterified MPP with $\mathrm{NaOH}$ was proposed for thin film development [119]. In this same study, the DE decreased when a higher volume $(\sim 3.0 \mathrm{~mL})$ of $1 \mathrm{~N} \mathrm{NaOH}$ at $25^{\circ} \mathrm{C}$ was employed in the preparation.

Wongkaew et al. [6] explained the industrial value chain process of MPP as illustrated in Figure 3. First, the biomass was dried and pectin extraction can be achieved with MAE techniques. The dried peel powder was suspended in diluted acidic solution (distilled $\mathrm{H}_{2} \mathrm{O}$ adjusted to $\mathrm{pH} 1.5$ with $2 \mathrm{M} \mathrm{HCl}$ ) and heated in a microwave oven followed by separating the residue from the solution using filtration technique. The liquid is combined with a 1:1 ethanol-water mixture to precipitate the pectin, and then it is separated by filtration. The pectin was dried at $40{ }^{\circ} \mathrm{C}$ until a consistent weight was attained. The final product can be applied to food additives or sources of prebiotic or in pharmaceutical application.

\subsection{Future Direction of MPP Utilisation}

Plant polysaccharides are vital for the modulation of human gut microbiota which can impact on health generally recognised as prebiotics [142]. Among the most common prebiotic candidates, pectin oligosaccharide (POS) is receiving attention in the functional food industry [143]. MPP can possibly be hydrolysed into small molecules of pectic oligosaccharide or MPOS, as shown in Figure 4 [144]. The MPOS obtained highly stimulated the probiotic growth as well as the total short-chain fatty acids (SCFAs) production of Bifidobacterium animalis TISTR 2195 and Lactobacillus reuteri DSM 17938. It is also confirmed in our previous study that the MPOS illustrates a high potential as a prebiotic property [141]. The subsequently obtained SCFAs provide a great variety of health effects, including inhibition of pathogenic bacteria, constipation relief, reduction in blood glucose levels, improvement in mineral absorption, reduction of colonic cancer and modulation of the immune system [145]. 


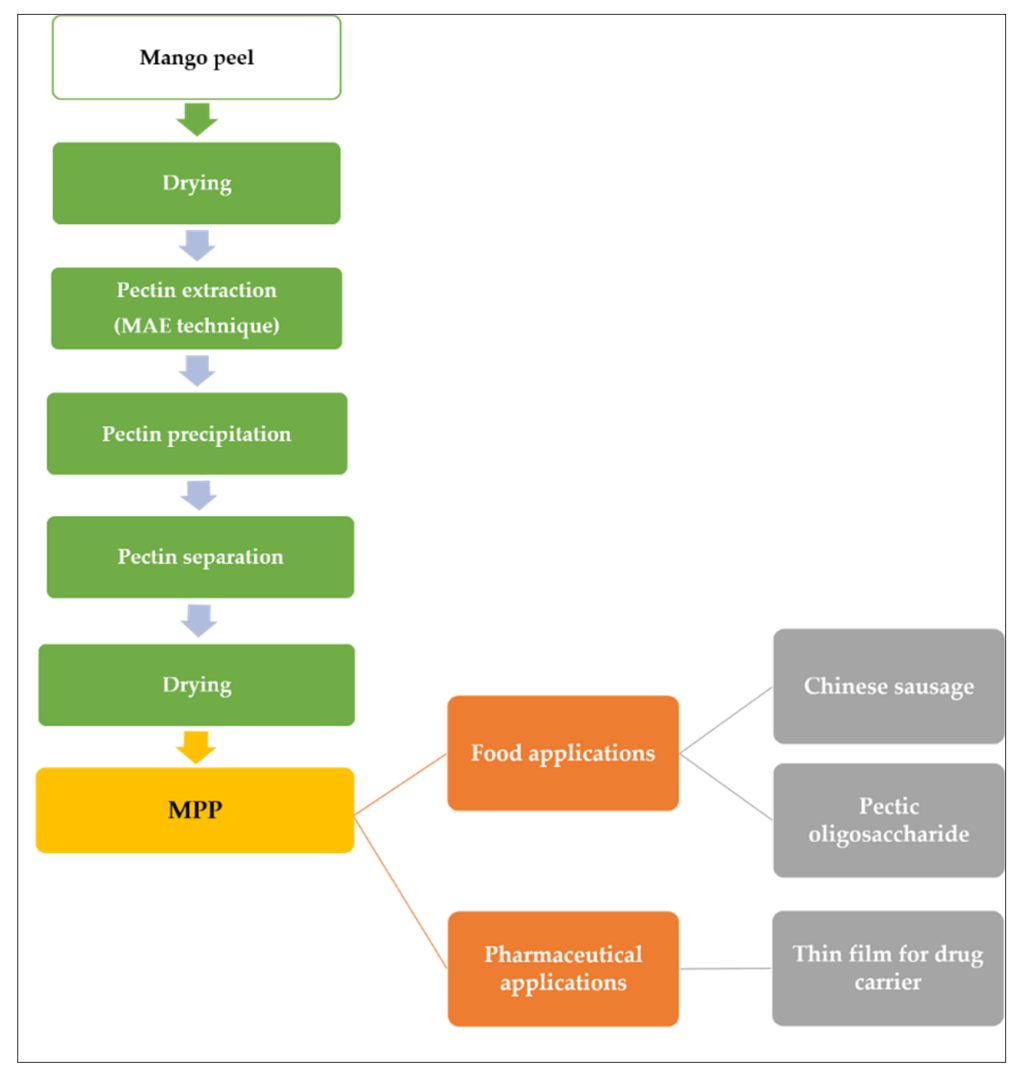

Figure 3. MPP value chain and applications.

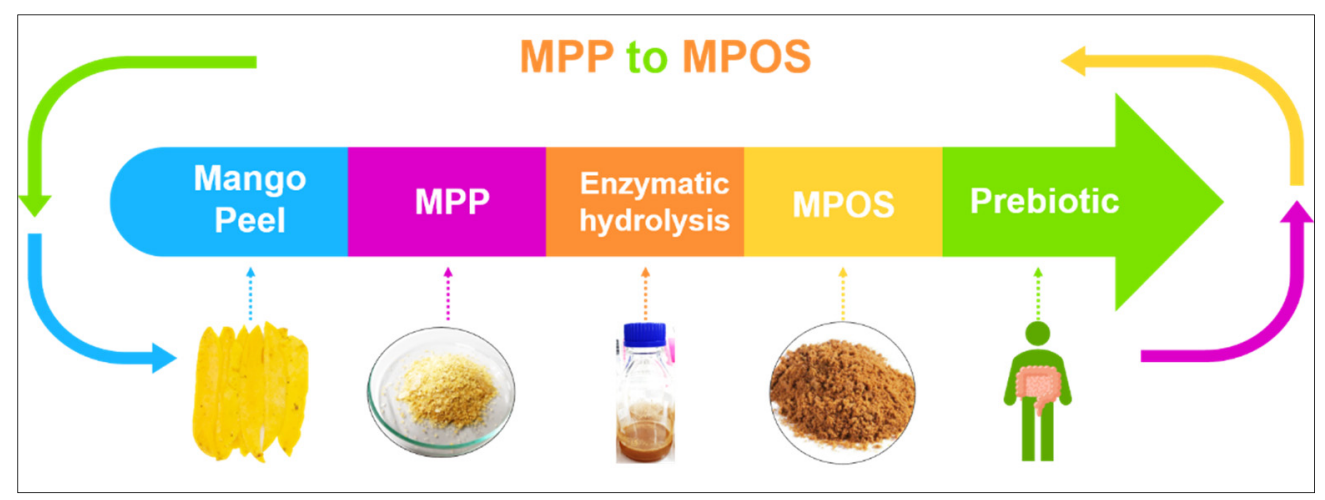

Figure 4. Future direction of MPP utilisation to MPOS production.

\section{Conclusions}

Peels account for around a quarter of the entire mango fruit which is generated during the large-scale processing. Mango peel pectin can be retrieved from this biomass and its functionality depends upon the physiochemical characteristics which are largely influenced by varieties and extraction techniques. The high methoxyl content of the recovered pectin limits its use as food additive only. This biopolymer is structurally conversed by the de-esterification with alkaline treatment, resulting in its extended use as packaging or pharmaceutical-drug carrier. Future direction is heading toward the use of this potential biopolymer as functional prebiotic ingredient. This review pulls together the landscape picture of mango peel pectin biopolymer and highlights the use of the biomass as alternative biorefinery material to encourage a global sustainable development approach. 
Author Contributions: Conceptualisation, S.R.S.; methodology, M.W., P.C. and S.R.S.; formal analysis, M.W. and P.C.; investigation, M.W., P.C. and S.R.S.; writing-original draft preparation, M.W. and P.C.; writing-review and editing, M.W., P.C. and S.R.S.; supervision, S.R.S., P.S., Y.P. and T.C.; project administration, M.W. and P.C.; funding acquisition, N.L., K.J., P.R., W.R. and P.J. All authors have read and agreed to the published version of the manuscript.

Funding: This research project was partially supported by Chiang Mai University.

Institutional Review Board Statement: Not applicable.

Informed Consent Statement: Not applicable.

Data Availability Statement: Not applicable.

Conflicts of Interest: The authors declare no conflict of interest. The funders had no role in the design of the study; in the collection, analyses, or interpretation of data; in the writing of the manuscript, or in the decision to publish the results.

\section{References}

1. Kumar, H.; Bhardwaj, K.; Sharma, R.; Nepovimova, E.; Kuča, K.; Dhanjal, D.S.; Verma, R.; Bhardwaj, P.; Sharma, S.; Kumar, D. Fruit and Vegetable Peels: Utilization of high value horticultural waste in novel industrial applications. Molecules 2020, $25,2812$. [CrossRef]

2. Antonic, B.; Jancikova, S.; Dordevic, D.; Tremlova, B. Apple pomace as food fortification ingredient: A systematic review and meta-analysis. J. Food Sci. 2020, 85, 2977-2985. [CrossRef]

3. Galanakis, C.M. Recovery of high added-value components from food wastes: Conventional, emerging technologies and commercialized applications. Trends Food Sci. Technol. 2012, 26, 68-87. [CrossRef]

4. Loeillet, D. The european mango market a promising tropical fruit. Fruits 1994, 49, 332-334.

5. Wongkaew, M.; Sangta, J.; Chansakaow, S.; Jantanasakulwong, K.; Rachtanapun, P.; Sommano, S.R. Volatile profiles from over-ripe purée of Thai mango varieties and their physiochemical properties during heat processing. PLoS ONE 2021, 16, e0248657. [CrossRef]

6. Wongkaew, M.; Kittiwachana, S.; Phuangsaijai, N.; Tinpovong, B.; Tiyayon, C.; Pusadee, T.; Chuttong, B.; Sringarm, K.; Bhat, F.M.; Sommano, S.R. Fruit characteristics, peel nutritional compositions, and their relationships with mango peel pectin quality. Plants 2021, 10, 1148. [CrossRef]

7. Larrauri, J.; Rupérez, P.; Borroto, B.; Saura-calixto, F. Mango peels as a new tropical fibre: Preparation and characterization. LWT-Food Sci. Technol. 1996, 29, 729-733. [CrossRef]

8. Chaiwarit, T.; Masavang, S.; Mahe, J.; Sommano, S.; Ruksiriwanich, W.; Brachais, C.-H.; Chambin, O.; Jantrawut, P. Mango (cv. Nam Dokmai) peel as a source of pectin and its potential use as a film-forming polymer. Food Hydrocoll. 2020, $102,105611$. [CrossRef]

9. Min, B.; Lim, J.; Ko, S.; Lee, K.-G.; Lee, S.H.; Lee, S. Environmentally friendly preparation of pectins from agricultural byproducts and their structural/rheological characterization. Bioresour. Technol. 2011, 102, 3855-3860. [CrossRef] [PubMed]

10. Sommano, S.; Ounamornmas, P.; Nisoa, M.; Sriwattana, S.; Page, P.; Colelli, G. Characterisation and physiochemical properties of mango peel pectin extracted by conventional and phase control microwave-assisted extractions. Int. Food Res. J. 2018, 25, 2657-2665.

11. Deeksha, K.; Sunita, M. Utilization of mango and its by-products by different processing methods. Asian J. Sci. Technol. 2020, 9 , 8896-8910.

12. Wongkaew, M.; Sommano, S.; Tangpao, T.; Rachtanapun, P.; Jantanasakulwong, K. Mango peel pectin by microwave-assisted extraction and its use as fat replacement in dried Chinese sausage. Foods 2020, 9, 450. [CrossRef]

13. Sommano, S.; Ounamornmas, P.; Nisoa, M.; Sriwattana, S. Bioactive functionality of pectin from peels of seven Thai mango cultivars. Acta Hortic. 2018, 423-428. [CrossRef]

14. Manthey, J.A.; Perkins-Veazie, P. Influences of harvest date and location on the levels of beta-carotene, ascorbic acid, total phenols, the in vitro antioxidant capacity, and phenolic profiles of five commercial varieties of mango (Mangifera indica L.). J. Agric. Food Chem. 2009, 57, 10825-10830. [CrossRef] [PubMed]

15. Schieber, A.; Berardini, N.; Carle, R. Identification of flavonol and xanthone glycosides from mango (Mangifera indica L. Cv. "Tommy Atkins") peels by high-performance liquid chromatography-electrospray ionization mass spectrometry. J. Agric. Food Chem. 2003, 51, 5006-5011. [CrossRef] [PubMed]

16. Ajila, C.M.; Bhat, S.G.; Prasada Rao, U.J.S. Valuable components of raw and ripe peels from two Indian mango varieties. Food Chem. 2007, 102, 1006-1011. [CrossRef]

17. Beerh, O.P.; Raghuramaiah, B.; Krishnamurthy, G.; Giridhar, N. Utilization of mango waste: Recovery of juice from waste pulp and peel. J. Food Sci. Technol. 1976, 13, 138-141.

18. Ajila, C.M.; Prasada Rao, U.J.S. Mango peel dietary fibre: Composition and associated bound phenolics. J. Funct. Foods 2013, 5, 444-450. [CrossRef] 
19. Garcia-Magana Mde, L.; Garcia, H.S.; Bello-Perez, L.A.; Sayago-Ayerdi, S.G.; de Oca, M.M. Functional properties and dietary fiber characterization of mango processing by-products (Mangifera indica L., cv Ataulfo and Tommy Atkins). Plant Foods Hum. Nutr. 2013, 68, 254-258. [CrossRef] [PubMed]

20. Malviya, R.; Kulkarni, G. Extraction and characterization of mango peel pectin as pharmaceutical excipient. Polym. Med. 2012, 42, 185-190.

21. Villegas, D.; Handford, M.; Alcalde, J.A.; Perez-Donoso, A. Exogenous application of pectin-derived oligosaccharides to grape berries modifies anthocyanin accumulation, composition and gene expression. Plant Physiol. Biochem. 2016, 104, 125-133. [CrossRef]

22. Ajila, C.M.; Jaganmohan Rao, L.; Prasada Rao, U.J.S. Characterization of bioactive compounds from raw and ripe Mangifera indica L. peel extracts. Food Chem. Toxicol. 2010, 48, 3406-3411. [CrossRef] [PubMed]

23. Güzel, M.; Akpınar, Ö. Valorisation of fruit by-products: Production characterization of pectins from fruit peels. Food Bioprod. Process. 2019, 115, 126-133. [CrossRef]

24. Macagnan, F.; Santos, L.; Roberto, B.; Moura, F.; Bizzani, M.; Silva, L. Biological properties of apple pomace, orange bagasse and passion fruit peel as alternative source of dietary fibre. Bioact. Carbohydr. Diet. Fibre 2015, 6, 1-6. [CrossRef]

25. Mohnen, D. Pectin structure and biosynthesis. Curr. Opin. Plant Biol. 2008, 11, 266-277. [CrossRef]

26. Freitas, C.M.; Coimbra, J.S.; Souza, V.G.; Sousa, R.C. Structure and applications of pectin in food, biomedical, and pharmaceutical industry: A review. Coatings 2021, 11, 922. [CrossRef]

27. Reddy, L.; Obulam, V.S.; Wee, Y.-J. Production of ethanol from mango (Mangifera indica L.) peel by Saccharomyces cerevisiae CFTRI101. Afr. J. Biotechnol. 2011, 10, 4183-4189.

28. Banerjee, J.; Singh, R.; Vijayaraghavan, R.; MacFarlane, D.; Patti, A.F.; Arora, A. A hydrocolloid based biorefinery approach to the valorisation of mango peel waste. Food Hydrocoll. 2018, 77, 142-151. [CrossRef]

29. Yingkamhaeng, N.; Sukyai, P. The potential of mango peel utilization for cellulose extraction by hydrothermal pretreatment. In Proceedings of the 26th Annual Meeting of the Thai Society for Biotechnology and International Conference, Chiang Rai, Thailand, 26-29 November 2014; pp. 107-109.

30. May, C.D. Industrial pectins: Sources, production and applications. Carbohydr. Polym. 1990, 12, 79-99. [CrossRef]

31. Belkheiri, A.; Forouhar, A.; Ursu, A.V.; Dubessay, P.; Pierre, G.; Delattre, C.; Djelveh, G.; Abdelkafi, S.; Hamdami, N.; Michaud, P. Extraction, characterization, and applications of pectins from plant by-products. Appl. Sci. 2021, 11, 6596. [CrossRef]

32. Méndez-Zamora, G.; García-Macías, J.A.; Santellano-Estrada, E.; Chávez-Martínez, A.; Durán-Meléndez, L.A.; Silva-Vázquez, R.; Quintero-Ramos, A. Fat reduction in the formulation of frankfurter sausages using inulin and pectin. Food Sci. Technol. 2015, 35, 25-31. [CrossRef]

33. Iqbal, M.; Saeed, A.; Kalim, I.J.S.S. Characterization of adsorptive capacity and investigation of mechanism of $\mathrm{Cu}^{2+}, \mathrm{Ni}^{2+}$ and $\mathrm{Zn}^{2+}$ adsorption on mango peel waste from constituted metal solution and genuine electroplating effluent. Sep. Sci. Technol. 2009, 44, 3770-3791. [CrossRef]

34. Jha, S.N.; Chopra, S.; Kingsly, A.R.P. Modeling of color values for nondestructive evaluation of maturity of mango. J. Food Eng. 2007, 78, 22-26. [CrossRef]

35. Malevski, Y.; Brito, L.; Peleg, M.; Silberg, M. External color as maturity index of mango. J. Food Sci. 2006, 42, 1316-1318. [CrossRef]

36. Burana-Osot, J.; Soonthornchareonnon, N.; Chaidedgumjorn, A.; Hosoyama, S.; Toida, T. Determination of galacturonic acid from pomelo pectin in term of galactose by HPAEC with fluorescence detection. Carbohydr. Polym. 2010, 81, 461-465. [CrossRef]

37. Nunak, N.; Suesut, T. Measuring Geometric Mean Diameter of fruits and vegetables using Light Sectioning Method. Songklanakarin J. Sci. Technol. 2009, 31, 629-633.

38. Nordey, T.; Léchaudel, M.; Saudreau, M.; Joas, J.; Génard, M. Model-assisted analysis of spatial and temporal variations in fruit temperature and transpiration highlighting the role of fruit development. PLoS ONE 2014, 9, e92532. [CrossRef]

39. Athmaselvi, K.; Jenney, P.; Pavithra, C.; Roy, I. Physical and biochemical properties of selected tropical fruits. Int. Agrophys. 2014, 28, 383-388. [CrossRef]

40. Nguyen, H.D.H.; Nguyen, H.V.H.; Savage, G.P. Properties of pectin extracted from Vietnamese mango peels. Foods $2019,8,629$. [CrossRef]

41. Lebaka, V.R.; Wee, Y.-J.; Ye, W.; Korivi, M. Nutritional Composition and bioactive compounds in three different parts of mango fruit. Int. J. Environ. Res. Public Health 2021, 18, 741. [CrossRef]

42. Abdualrahm, M. Physico-chemical characteristics of different types of mango (Mangifera indica L.) fruits grown in Drafur regions and its use in jam processing. Sci. Int. 2013, 1, 144-147. [CrossRef]

43. Madalageri, D.D.; Bharati, P.; Kage, U. Physicochemical properties, nutritional and antinutritional composition of pulp and peel of three mango varieties. Int. J. Educ. Sci. Res. 2017, 7, 81-94.

44. Vieira, W.A.S.; Michereff, S.J.; de Morais, M.A.; Hyde, K.D.; Câmara, M.P.S. Endophytic species of Colletotrichum associated with mango in northeastern Brazil. Fungal Divers. 2014, 67, 181-202. [CrossRef]

45. Larrauri, J. New approaches in the preparation of high dietary fibre powders from fruit by-products. Trends Food Sci. Technol. 1999, 10, 3-8. [CrossRef]

46. Larrauri, J.; Rupérez, P.; Bravo, L.; Saura-Calixto, F. High dietary fibre powders from orange and lime peels: Associated polyphenols and antioxidant capacity. Food Res. Int. 1996, 29, 757-762. [CrossRef] 
47. Marín, F.R.; Soler-Rivas, C.; Benavente-García, O.; Castillo, J.; Pérez-Alvarez, J.A. By-products from different citrus processes as a source of customized functional fibres. Food Chem. 2007, 100, 736-741. [CrossRef]

48. Abbasi, A.; Guo, X.; Fu, X.; Zhou, L.; Chen, Y.; Zhu, Y.; Yan, H.; Liu, R. Comparative assessment of phenolic content and in vitro antioxidant capacity in the pulp and peel of mango cultivars. Int. J. Mol. Sci. 2015, 16, 13507-13527. [CrossRef]

49. Tokas, J.P.H.; Baloda, S.; Sheokand, R.N. Mango peel a potential source of bioactive compounds and phytochemicals. Austin Food Sci. 2020, 5, 1-7.

50. Berardini, N.; Fezer, R.; Conrad, J.; Beifuss, U.; Carle, R.; Schieber, A. Screening of Mango (Mangifera indica L.) Cultivars for their contents of flavonol o- and xanthone c-glycosides, anthocyanins, and pectin. J. Agric. Food Chem. 2005, 53, 1563-1570. [CrossRef]

51. Lakshminarayana, S.; Subhadra, N.V.; Subramanyam, H. Some aspects of developmental physiology of the mango fruit. J. Hortic. Sci. 1970, 45, 133-142. [CrossRef]

52. Luo, F.; Lv, Q.; Zhao, Y.; Hu, G.; Huang, G.; Zhang, J.; Sun, C.; Li, X.; Chen, K. Quantification and purification of mangiferin from Chinese mango (Mangifera indica L.) cultivars and its protective effect on human umbilical vein endothelial cells under $\mathrm{H}_{2} \mathrm{O}_{2}$-induced stress. Int. J. Mol. Sci. 2012, 13, 11260-11274. [CrossRef] [PubMed]

53. Ramirez, J.E.; Zambrano, R.; Sepúlveda, B.; Simirgiotis, M.J. Antioxidant properties and hyphenated HPLC-PDA-MS profiling of Chilean Pica mango fruits (Mangifera indica L. Cv. piqueño). Molecules 2013, 19, 438-458. [CrossRef] [PubMed]

54. Telang, M.; Dhulap, S.; Mandhare, A.; Hirwani, R. Therapeutic and cosmetic applications of mangiferin: A patent review. Expert Opin. Ther. Patents 2013, 23, 1561-1580. [CrossRef]

55. Imran, M.; Arshad, M.S.; Butt, M.S.; Kwon, J.-H.; Sultan, M.T. Mangiferin: A natural miracle bioactive compound against lifestyle related disorders. Lipids Health Dis. 2017, 16, 1-17. [CrossRef]

56. Giampieri, F.; Alvarez-Suarez, J.M.; Mazzoni, L.; Forbes-Hernandez, T.Y.; Gasparrini, M.; Gonzàlez-Paramàs, A.M.; Santos-Buelga, C.; Quiles, J.L.; Bompadre, S.; Mezzetti, B.; et al. An anthocyanin-rich strawberry extract protects against oxidative stress damage and improves mitochondrial functionality in human dermal fibroblasts exposed to an oxidizing agent. Food Funct. 2014, 5, 1939-1948. [CrossRef] [PubMed]

57. Rahman, M.M.; Ichiyanagi, T.; Komiyama, T.; Sato, S.; Konishi, T. Effects of anthocyanins on psychological stress-induced oxidative stress and neurotransmitter status. J. Agric. Food Chem. 2008, 56, 7545-7550. [CrossRef]

58. Ranganath, K.G.; Shivashankara, K.S.; Roy, T.K.; Dinesh, M.R.; Geetha, G.A.; Pavithra, K.C.; Ravishankar, K.V. Profiling of anthocyanins and carotenoids in fruit peel of different colored mango cultivars. J. Food Sci. Technol. 2018, 55, 4566-4577. [CrossRef]

59. Kayesh, E.; Shangguan, L.; Korir, N.K.; Sun, X.; Bilkish, N.; Zhang, Y.; Han, J.; Song, C.; Cheng, Z.-M.; Fang, J. Fruit skin color and the role of anthocyanin. Acta Physiol. Plant. 2013, 35, 2879-2890. [CrossRef]

60. El Gharras, H. Polyphenols: Food sources, properties and applications-A review. Int. J. Food Sci. Technol. 2009, 44, 2512-2518. [CrossRef]

61. Ribeiro, S.M.R.; Barbosa, L.C.A.; Queiroz, J.H.; Knödler, M.; Schieber, A. Phenolic compounds and antioxidant capacity of Brazilian mango (Mangifera indica L.) varieties. Food Chem. 2008, 110, 620-626. [CrossRef]

62. Meléndez-Martínez, A.J. An overview of carotenoids, apocarotenoids, and vitamin a in agro-food, nutrition, health, and disease. Mol. Nutr. Food Res. 2019, 63, e1801045. [CrossRef] [PubMed]

63. Melendez-Martinez, A.J.; Mapelli-Brahm, P.; Stinco, C.M. The colourless carotenoids phytoene and phytofluene: From dietary sources to their usefulness for the functional foods and nutricosmetics industries. J. Food Compos. Anal. 2018, 67, 91-103. [CrossRef]

64. Meléndez-Martínez, A.J.; Mandić, A.I.; Bantis, F.; Böhm, V.; Borge, G.I.A.; Brnčić, M.; Bysted, A.; Cano, M.P.; Dias, M.G.; Elgersma, A. A comprehensive review on carotenoids in foods and feeds: Status quo, applications, patents, and research needs. Crit. Rev. Food Sci. Nutr. 2021, 1-51. [CrossRef] [PubMed]

65. Akther, S.; Sultana, A.; Badsha, R.; Rahman, M.; Alim, A.; Amin, A.M. Physicochemical properties of mango (Amropali cultivar) powder and its reconstituted product as affected by drying methods. Int. J. Food Prop. 2020, 23, 2201-2216. [CrossRef]

66. Burton-Freeman, B.M.; Sandhu, A.K.; Edirisinghe, I. Mangos and their bioactive components: Adding variety to the fruit plate for health. Food Funct. 2017, 8, 3010-3032. [CrossRef]

67. Maldonado-Celis, M.E.; Yahia, E.M.; Bedoya, R.; Landázuri, P.; Loango, N.; Aguillón, J.; Restrepo, B.; Ospina, J.C.G. Chemical composition of mango (Mangifera indica L.) fruit: Nutritional and phytochemical compounds. Front. Plant Sci. 2019, 10, 1073. [CrossRef]

68. Saleem Dar, M.; Oak, P.; Chidley, H.; Deshpande, A.; Giri, A.; Gupta, V. Chapter 19-Nutrient and flavor content of mango (Mangifera indica L.) cultivars: An appurtenance to the list of staple foods. In Nutritional Composition of Fruit Cultivars; Simmonds, M.S.J., Preedy, V.R., Eds.; Academic Press: San Diego, CA, USA, 2016; pp. 445-467.

69. Tharanathan, R.N.; Yashoda, H.M.; Prabha, T.N. Mango (Mangifera indica L.), "The King of Fruits"-An overview. Food Rev. Int. 2006, 22, 95-123. [CrossRef]

70. Arumugam, R. Fermentation of pretreated hydrolyzates of banana and mango fruit wastes for ethanol production. Asian J. Exp. Biol. Sci. 2011, 2, 246-256.

71. Sadineni, V.; Kumar, Y.; Obulam, V.S. Carotenoid composition of mango (Mangifera indica L.) wine and its antioxidant activity. J. Food Biochem. 2011, 35, 1538-1547. [CrossRef]

72. Kumar, D.; Ashfaque, M.; Muthukumar, M.; Singh, M.; Garg, N. Production and characterization of carboxymethyl cellulase from Paenibacillus polymyxa using mango peel as substrate. J. Environ. Biol. 2012, 33, 81-84. 
73. Kumar, Y.S.; Kumar, P.V.; Reddy, O.V.S. Pectinase production from mango peel using Aspergillus foetidusand its application in processing of mango juice. Food Biotechnol. 2012, 26, 107-123. [CrossRef]

74. Saravanan, P.; Muthuvelayudham, R.; Thangavelu, V. Application of Statistical Design for the Production of Cellulase by Trichoderma reesei Using Mango Peel. Enzym. Res. 2012, 2012, 157643. [CrossRef] [PubMed]

75. Jawad, A.H.; Alkarkhi, A.; Ogugbue, C.; Easa, A.; Norulaini, N. Production of the lactic acid from mango peel waste-Factorial experiment. J. King Saud Univ. Sci. 2013, 25, 39-45. [CrossRef]

76. Rashad, M.M.; Moharib, S.A.; Jwanny, E.W. Yeast conversion of mango waste or methanol to single cell protein and other metabolites. Biol. Wastes 1990, 32, 277-284. [CrossRef]

77. Kumar, C.S.C.; Mythily, R.; Chandraju, S. Utilization of mango peels (Mangifera indica) for the extraction of sugars. Der Pharma Chem. 2012, 4, 2422-2426.

78. Ajila, C.; Aalami, M.; Leelavathi, K.; Rao, U.P. Mango peel powder: A potential source of antioxidant and dietary fiber in macaroni preparations. Innov. Food Sci. Emerg. Technol. 2010, 11, 219-224. [CrossRef]

79. Palmeira, S.; Gois, L.M.; Souza, L.D. Extraction of phenolic compounds from mango peels. Lat. Am. Appl. Res. 2012, 42, 77-81.

80. Tunchaiyaphum, S.; Eshtiaghi, M.N.; Yoswathana, N. Extraction of bioactive compounds from mango peels using green technology. Int. J. Chem. Eng. Appl. 2013, 4, 194-198. [CrossRef]

81. Aziz, N.A.A.; Wong, L.M.; Bhat, R.; Cheng, L.H. Evaluation of processed green and ripe mango peel and pulp flours (Mangifera indica var. Chokanan) in terms of chemical composition, antioxidant compounds and functional properties. J. Sci. Food Agric. 2011, 92, 557-563. [CrossRef]

82. Ruiz, C.; Ramírez, C.; Piñeres, C.; Angulo, M.; Hedreira, J. Obtaining and characterization of mango peel powder and its use as a source of fiber and a functional ingredient in natural yogurt. In Proceedings of the 11th International Congress on Engineering and Food (ICEF11), Athens, Greece, 22-26 May 2011.

83. Abdeldaiem, M.H.; Ali, G.M.H. Use of irradiated mango (Mangifera Indica) peels powder as potential source of dietary fiber and antioxidant in beef burger. J. Appl. Sci. Res. 2012, 8, 3677-3687.

84. Iqbal, M.; Saeed, A.; Zafar, S.I. FTIR spectrophotometry, kinetics and adsorption isotherms modeling, ion exchange, and EDX analysis for understanding the mechanism of $\mathrm{Cd}^{2+}$ and $\mathrm{Pb}^{2+}$ removal by mango peel waste. J. Hazard. Mater. 2009, 164, 161-171. [CrossRef] [PubMed]

85. Malviya, R.; Srivastava, P.; Bansal, M.; Sharma, P. Mango peel pectin as superdisintegrating agent. J. Sci. Ind. Res. 2010, 69, 688-690.

86. Gentilini, R.; Bozzini, S.; Munarin, F.; Petrini, P.; Visai, L.; Tanzi, M.C. Pectins from Aloe Vera: Extraction and production of gels for regenerative medicine. J. Appl. Polym. Sci. 2014, 131, 1-9. [CrossRef]

87. Peng, K.; Zhang, Y.; Wang, S.; Liao, X.; Hu, X. Effect of microwave drying pretreatment on extraction of pectin from apple pomace. Int. Food Res. J. 2008, 24, 222-226.

88. Casas-Orozco, D.; Villa, A.L.; Bustamante, F.; Gonzalez-Rodriguez, L.-M. Process development and simulation of pectin extraction from orange peels. Food Bioprod. Process. 2015, 96, 86-98. [CrossRef]

89. Georgiev, Y.; Ognyanov, M.; Yanakieva, I.; Kussovski, V.; Kratchanova, M. Isolation, characterization and modification of citrus pectins. J. Biosci. Biotechnol. 2013, 2012, 223-233.

90. Marić, M.; Grassino, A.N.; Zhu, Z.; Barba, F.J.; Brnčić, M.; Brnčić, S.R. An overview of the traditional and innovative approaches for pectin extraction from plant food wastes and by-products: Ultrasound-, microwaves-, and enzyme-assisted extraction. Trends Food Sci. Technol. 2018, 76, 28-37. [CrossRef]

91. Oliveira, A.D.N.; Paula, D.D.A.; de Oliveira, E.B.; Saraiva, S.H.; Stringheta, P.C.; Ramos, A.M. Optimization of pectin extraction from Ubá mango peel through surface response methodology. Int. J. Biol. Macromol. 2018, 113, 395-402. [CrossRef]

92. Maran, J.P.; Sivakumar, V.; Thirugnanasambandham, K.; Sridhar, R. Optimization of microwave assisted extraction of pectin from orange peel. Carbohydr. Polym. 2013, 97, 703-709. [CrossRef] [PubMed]

93. Maran, J.P.; Prakash, K.A. Process variables influence on microwave assisted extraction of pectin from waste Carcia papaya L. peel. Int. J. Biol. Macromol. 2015, 73, 202-206. [CrossRef] [PubMed]

94. Pandit, S.G.; Vijayanand, P.; Kulkarni, S. Pectic principles of mango peel from mango processing waste as influenced by microwave energy. LWT 2015, 64, 1010-1014. [CrossRef]

95. Kratchanova, M.; Pavlova, E.; Panchev, I. The effect of microwave heating of fresh orange peels on the fruit tissue and quality of extracted pectin. Carbohydr. Polym. 2004, 56, 181-185. [CrossRef]

96. Fissore, E.N.; Ponce, N.M.; Wider, E.A.; Stortz, C.A.; Gerschenson, L.N.; Rojas, A.M. Commercial cell wall hydrolytic enzymes for producing pectin-enriched products from butternut (Cucurbita moschata, Duchesne ex Poiret). J. Food Eng. 2009, 93, $293-301$. [CrossRef]

97. Puri, M.; Sharma, D.; Barrow, C.J. Enzyme-assisted extraction of bioactives from plants. Trends Biotechnol. 2012, 30, 37-44. [CrossRef] [PubMed]

98. Poojary, M.M.; Orlien, V.; Passamonti, P.; Olsen, K. Enzyme-assisted extraction enhancing the umami taste amino acids recovery from several cultivated mushrooms. Food Chem. 2017, 234, 236-244. [CrossRef]

99. Roselló-Soto, E.; Parniakov, O.; Deng, Q.; Patras, A.; Koubaa, M.; Grimi, N.; Boussetta, N.; Tiwari, B.K.; Vorobiev, E.; Lebovka, N. Application of non-conventional extraction methods: Toward a sustainable and green production of valuable compounds from mushrooms. Food Eng. Rev. 2016, 8, 214-234. [CrossRef] 
100. Dominiak, M.; Søndergaard, K.M.; Wichmann, J.; Vidal-Melgosa, S.; Willats, W.G.; Meyer, A.S.; Mikkelsen, J.D. Application of enzymes for efficient extraction, modification, and development of functional properties of lime pectin. Food Hydrocoll. 2014, 40, 273-282. [CrossRef]

101. Liew, S.; Chin, N.; Yusof, Y.; Sowndhararajan, K. Comparison of acidic and enzymatic pectin extraction from passion fruit peels and its gel properties. J. Food Process. Eng. 2016, 39, 501-511. [CrossRef]

102. Dranca, F.; Oroian, M. Optimization of pectin enzymatic extraction from malus domestica 'fălticeni' apple pomace with Celluclast 1.5L. Molecules 2019, 24, 2158. [CrossRef]

103. Zinoviadou, K.G.; Galanakis, C.; Brnčić, M.; Grimi, N.; Boussetta, N.; Mota, M.; Saraiva, J.A.; Patras, A.; Tiwari, B.K.; Barba, F.J. Fruit juice sonication: Implications on food safety and physicochemical and nutritional properties. Food Res. Int. 2015, 77, 743-752. [CrossRef]

104. Barba, F.J.; Brianceau, S.; Turk, M.; Boussetta, N.; Vorobiev, E. Effect of alternative physical treatments (ultrasounds, pulsed electric fields, and high-voltage electrical discharges) on selective recovery of bio-compounds from fermented grape pomace. Food Bioprocess Technol. 2015, 8, 1139-1148. [CrossRef]

105. Zhu, Z.; Wu, Q.; Di, X.; Li, S.; Barba, F.J.; Koubaa, M.; Roohinejad, S.; Xiong, X.; He, J. Multistage recovery process of seaweed pigments: Investigation of ultrasound assisted extraction and ultra-filtration performances. Food Bioprod. Process. 2017, 104, 40-47. [CrossRef]

106. Guandalini, B.B.V.; Rodrigues, N.P.; Marczak, L.D.F. Sequential extraction of phenolics and pectin from mango peel assisted by ultrasound. Food Res. Int. 2019, 119, 455-461. [CrossRef]

107. Zakaria, S.M.; Kamal, S.M.M. Subcritical water extraction of bioactive compounds from plants and algae: Applications in pharmaceutical and food ingredients. Food Eng. Rev. 2016, 8, 23-34. [CrossRef]

108. Xia, H.; Matharu, A.S. Unavoidable food supply chain waste: Acid-free pectin extraction from mango peel via subcritical water. Faraday Discuss. 2017, 202, 31-42. [CrossRef]

109. Bagherian, H.; Ashtiani, F.Z.; Fouladitajar, A.; Mohtashamy, M. Comparisons between conventional, microwave- and ultrasoundassisted methods for extraction of pectin from grapefruit. Chem. Eng. Process. Process. Intensif. 2011, 50, 1237-1243. [CrossRef]

110. Fishman, M.L.; Chau, H.K.; Hoagland, P.; Ayyad, K. Characterization of pectin, flash-extracted from orange albedo by microwave heating, under pressure. Carbohydr. Res. 1999, 323, 126-138. [CrossRef]

111. Adetunji, L.R.; Adekunle, A.; Orsat, V.; Raghavan, V. Advances in the pectin production process using novel extraction techniques: A review. Food Hydrocoll. 2017, 62, 239-250. [CrossRef]

112. Ptichkina, N.; Markina, O.; Rumyantseva, G. Pectin extraction from pumpkin with the aid of microbial enzymes. Food Hydrocoll. 2008, 22, 192-195. [CrossRef]

113. Sowbhagya, H.B.; Chitra, V.N. Enzyme-assisted extraction of flavorings and colorants from plant materials. Crit. Rev. Food Sci. Nutr. 2010, 50, 146-161. [CrossRef]

114. Wikiera, A.; Mika, M.; Grabacka, M. Multicatalytic enzyme preparations as effective alternative to acid in pectin extraction. Food Hydrocoll. 2015, 44, 156-161. [CrossRef]

115. Azmir, J.; Zaidul, I.S.M.; Rahman, M.M.; Sharif, K.M.; Mohamed, A.; Sahena, F.; Jahurul, M.H.A.; Ghafoor, K.; Norulaini, N.A.N.; Omar, A.K.M. Techniques for extraction of bioactive compounds from plant materials: A review. J. Food Eng. 2013, 117, 426-436. [CrossRef]

116. Wang, L.; Weller, C.L. Recent advances in extraction of nutraceuticals from plants. Trends Food Sci. Technol. 2006, 17, 300-312. [CrossRef]

117. Ueno, H.; Tanaka, M.; Hosino, M.; Sasaki, M.; Goto, M. Extraction of valuable compounds from the flavedo of Citrus junos using subcritical water. Sep. Purif. Technol. 2008, 62, 513-516. [CrossRef]

118. Khajavi, S.H.; Kimura, Y.; Oomori, T.; Matsuno, R.; Adachi, S. Degradation kinetics of monosaccharides in subcritical water. J. Food Eng. 2005, 68, 309-313. [CrossRef]

119. Chaiwarit, T.; Rachtanapun, P.; Kantrong, N.; Jantrawut, P. Preparation of clindamycin hydrochloride loaded de-esterified low-methoxyl mango peel pectin film used as a topical drug delivery system. Polymers 2020, 12, 1006. [CrossRef] [PubMed]

120. Thibault, J.F.; Ralet, M.-C. Physico-Chemical Properties of Pectins in the Cell Walls and After Extraction; Springer: Berlin/Heidelberg, Germany, 2003; pp. 91-105.

121. Wang, M.; Huang, B.; Fan, C.; Zhao, K.; Hu, H.; Xu, X.; Pan, S.; Liu, F. Characterization and functional properties of mango peel pectin extracted by ultrasound assisted citric acid. Int. J. Biol. Macromol. 2016, 91, 794-803. [CrossRef]

122. Melton, L.D.; Smith, B.G. Determining the degree of methylation and acetylation of pectin. Curr. Protoc. Food Anal. Chem. 2001, 1, E3.4.1-E3.4.6. [CrossRef]

123. Moreira, M.M.; Guido, L.F.; Cruz, J.M.; Barros, A.A. Determination of galacturonic acid content in pectin from fruit juices by liquid chromatographydiode array detection-electrospray ionization tandem mass spectrometry. Open Chem. 2010, 8, 1236-1243. [CrossRef]

124. Gnanasambandam, R.; Proctor, A. Preparation of soy hull pectin. Food Chem. 1999, 65, 461-467. [CrossRef]

125. Salminen, H.; Weiss, J. Effect of pectin type on association and ph stability of whey protein-Pectin complexes. Food Biophys. 2013, 9, 29-38. [CrossRef]

126. Yavuz-Düzgün, M.; Zeeb, B.; Dreher, J.; Özçelik, B.; Weiss, J. The impact of esterification degree and source of pectins on complex coacervation as a tool to mask the bitterness of potato protein isolates. Food Biophys. 2020, 15, 376-385. [CrossRef] 
127. Brouns, F.; Theuwissen, E.; Adam, A.; Bell, M.G.; Berger, A.P.A.; Mensink, R.P. Cholesterol-lowering properties of different pectin types in mildly hyper-cholesterolemic men and women. Eur. J. Clin. Nutr. 2012, 66, 591-599. [CrossRef]

128. Pinheiro, E.s.R.; Silva, I.M.; Gonzaga, L.V.; Amante, E.R.; Teófilo, R.F.; Ferreira, M.M.; Amboni, R.D. Optimization of extraction of high-ester pectin from passion fruit peel (Passiflora edulis flavicarpa) with citric acid by using response surface methodology. Bioresour. Technol. 2008, 99, 5561-5566. [CrossRef] [PubMed]

129. Maness, N.O.; Ryan, J.D.; Mort, A.J. Determination of the degree of methyl esterification of pectins in small samples by selective reduction of esterified galacturonic acid to galactose. Anal. Biochem. 1990, 185, 346-352. [CrossRef]

130. Chinnici, F.; Spinabelli, U.; Riponi, C.; Amati, A. Optimization of the determination of organic acids and sugars in fruit juices by ion-exclusion liquid chromatography. J. Food Compos. Anal. 2005, 18, 121-130. [CrossRef]

131. Kermani, Z.J.; Shpigelman, A.; Pham, T.T.H.; Van Loey, A.; Hendrickx, M.E. Functional properties of citric acid extracted mango peel pectin as related to its chemical structure. Food Hydrocoll. 2015, 44, 424-434. [CrossRef]

132. Nagel, A.; Neidhart, S.; Anders, T.; Elstner, P.; Korhummel, S.; Sulzer, T.; Wulfkühler, S.; Winkler, C.; Qadri, S.; Rentschler, C. Improved processes for the conversion of mango peel into storable starting material for the recovery of functional co-products. Ind. Crop. Prod. 2014, 61, 92-105. [CrossRef]

133. Geerkens, C.H.; Nagel, A.; Just, K.M.; Miller-Rostek, P.; Kammerer, D.R.; Schweiggert, R.M.; Carle, R. Mango pectin quality as influenced by cultivar, ripeness, peel particle size, blanching, drying, and irradiation. Food Hydrocoll. 2015, 51, 241-251. [CrossRef]

134. Sharma, B.R.; Dhuldhoya, N.; Merchant, S.U.; Merchant, U. An overview on pectins. Times Food Proc. J. 2006, $23,44-51$.

135. Koubala, B.; Kansci, G.; Mbome, L.; Crépeau, M.-J.; Thibault, J.-F.; Ralet, M.-C. Effect of extraction conditions on some physicochemical characteristics of pectins from "Améliorée" and "Mango" mango peels. Food Hydrocoll. 2008, 22, 1345-1351. [CrossRef]

136. Willats, W.G.; Knox, P.; Mikkelsen, J.D. Pectin: New insights into an old polymer are starting to gel. Trends Food Sci. Technol. 2006, 17, 97-104. [CrossRef]

137. Thakur, B.R.; Singh, R.K.; Handa, A.K.; Rao, M.A. Chemistry and uses of pectin-A review. Crit. Rev. Food Sci. Nutr. 1997, 37, 47-73. [CrossRef]

138. Ciurzyńska, A.; Szerszeń, J.; Lenart, A. Pectin-A functional component of diet. Int. J. Res. Stud. Sci. Eng. Technol. 2016, 3, 20-27.

139. Zhang, Y.; Rempel, C.; McLaren, D. Chapter 12-Edible coating and film materials: Carbohydrates. In Innovations in Food Packaging; Elsevier: Amsterdam, The Netherlands, 2013; pp. 305-323.

140. Speiser, R.; Copley, M.J.; Nutting, G.C. Effect of molecular association and charge distribution on the gelation of pectin. J. Phys. Chem. 1947, 51, 117-133. [CrossRef]

141. Wongkaew, M.; Tinpovong, B.; Sringarm, K.; Leksawasdi, N.; Jantanasakulwong, K.; Rachtanapun, P.; Hanmoungjai, P.; Sommano, S. Crude pectic oligosaccharide recovery from Thai Chok Anan mango peel using pectinolytic enzyme hydrolysis. Foods 2021, 10, 627. [CrossRef]

142. Gibson, G.R.; Roberfroid, M.B. Dietary modulation of the human colonic microbiota-introducing the concept of prebiotics. J. Nutr. 1995, 125, 1401-1412. [CrossRef]

143. Zhang, S.; Hu, H.; Wang, L.; Liu, F.; Pan, S. Preparation and prebiotic potential of pectin oligosaccharides obtained from citrus peel pectin. Food Chem. 2018, 244, 232-237. [CrossRef] [PubMed]

144. Chung, W.S.F.; Meijerink, M.; Zeuner, B.; Holck, J.; Louis, P.; Meyer, A.S.; Wells, J.M.; Flint, H.J.; Duncan, S.H. Prebiotic potential of pectin and pectic oligosaccharides to promote anti-inflammatory commensal bacteria in the human colon. FEMS Microbiol. Ecol. 2017, 93, fix127. [CrossRef]

145. Gullón, B.; Gómez, B.; Martínez-Sabajanes, M.; Yáñez, R.; Parajó, J.C.; Alonso, J.L. Pectic oligosaccharides: Manufacture and functional properties. Trends Food Sci. Technol. 2013, 30, 153-161. [CrossRef] 